\title{
Hardwick and the Right of Privacy
}

\author{
Norman Vieira $\dagger$
}

In a recent essay in these pages, ${ }^{1}$ Thomas Stoddard castigated the Supreme Court for its decision in Bowers $v$ Hardwick, ${ }^{2}$ which held that the constitutional right of privacy does not protect private sexual conduct between consenting members of the same sex. Mr. Stoddard characterized Hardwick as an act of "judicial selfindulgence" and as "decision making by fiat rather than reason." It is easy to understand Mr. Stoddard's sense of outrage. The decision in Hardwick is fundamentally at odds with the philosophy that prevailed in earlier cases involving the right of privacy. The result therefore gives every appearance of resting on "the collective distaste of . . . the majority for the conduct under scrutiny." One should ask, however, whether the problem lies with the Hardwick decision or with the doctrine that the Court was asked to apply. I believe Mr. Stoddard has delivered the right message but has directed it at the wrong target. In this essay, I tender some observations on the Hardwick case and its principal antecedents. Because I conclude that the problem of unprincipled decision making in this area is rooted in underlying doctrinal deficiencies, and not merely in the shortcomings of the Hardwick opinion, I suggest a need to explore an alternative to the new substantive due process.

I.

Michael Hardwick was arrested in 1982 for engaging in an oral sex act in the bedroom of his home in violation of Georgia's antisodomy statute. ${ }^{5}$ After a preliminary hearing, the district attorney decided not to continue the prosecution in the absence of addi-

$\dagger$ Professor of Law, Southern Illinois University; A.B. 1959, Columbia University; J.D. 1962, University of Chicago.

1 Thomas B. Stoddard, Bowers v. Hardwick: Precedent by Personal Predilection, 54 U Chi L Rev 648 (1987).

2478 US 186 (1986).

3 Stoddard, 54 U Chi L Rev at 656, 649 (cited in note 1).

Id at 649.

- Hardwick v Bowers, 760 F2d 1202, 1204 (11th Cir 1985), rev'd 478 US 186 (1986); Ga Code Ann § 16-6-2 (1984) (prohibiting oral and anal sex between any two persons). 
tional evidence. ${ }^{6}$ Hardwick then brought suit in a federal district court, stating that he was an active homosexual and seeking a declaratory judgment that the statute was unconstitutional. The district court granted a motion to dismiss for failure to state a claim. ${ }^{7}$ The Eleventh Circuit reversed that judgment, holding that "the Georgia sodomy statute implicates a fundamental right" of privacy and could be enforced only if the state proved that "it has a compelling interest in regulating [Hardwick's] behavior and that this statute is the most narrowly drawn means of safeguarding that in-

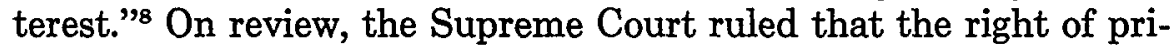
vacy does not shield homosexual sodomy from state criminal sanctions. $^{9}$ In a remarkably brief opinion, Justice White, who wrote for a five-member majority, distinguished Hardwick from the privacy cases extending from Griswold to Roe. ${ }^{10}$ " $[\mathrm{N}]$ one of the rights announced in those cases bears any resemblance to the claimed constitutional right of homosexuals to engage in acts of sodomy . . . . No connection between family, marriage, or procreation on the one hand and homosexual activity on the other has been demonstrated "11 The Court then invoked historical and institutional grounds for rejecting Hardwick's claim.

Mr. Stoddard objects to the Court's focus on family, marriage and procreation as "little more than judgment by pigeonhole."12 No doubt the Hardwick Court was attempting to confine the reach of the privacy cases by limiting them to their facts. This is a familiar technique for restricting the precedential value of disfavored decisions and is not necessarily unprincipled. But even a decision to limit the privacy cases to family, marriage, and procreation could not adequately explain the result in Hardwick. Admittedly, there is no connection between homosexual activity and procreation, except perhaps the kind of negative connection that exists between procreation and heterosexual use of contraceptives. ${ }^{13}$ But it is not self-evident that homosexual relations have no connection with "family" matters. A homosexual father, for example, might well seek a parenting partner for many of the same reasons that

- Hardwick, 478 US at 188.

${ }^{7}$ Id.

Hardwick, 760 F2d at 1212-13.

- Hardwick, 478 US at 195-96.

10 Griswold v Connecticut, 381 US 479 (1965); Roe v Wade, 410 US 113 (1973).

11 Hardwick, 478 US at 190-91.

12 Stoddard, $54 \mathrm{U}$ Chi L Rev at 653 (cited in note 1).

${ }^{13}$ See Eisenstadt $v$ Baird, 405 US 438, 453 (1972) (linking right of privacy with right to choose not to beget a child). 
would motivate an unmarried heterosexual parent to seek a partner. ${ }^{14}$ Unless one assumes that the term "family" embraces only heterosexual relationships, it is not clear that a homosexual couple cannot enter a family-like relationship that, except for the form of sexual expression, is similar to that of a traditional heterosexual couple.

Nor is Hardwick's reliance on the absence of marriage persuasive. Courts have consistently held that the right to marry is limited to heterosexual couples. ${ }^{15}$ This prohibition on homosexual marriage rests largely on the same set of assumptions as the ban on homosexual sodomy. ${ }^{16}$ It is difficult to argue, except in a catch22 universe, that homosexual sodomy is unprotected for want of marriage when state laws preclude homosexual marriages and when those laws raise essentially the same issues as the controls on sodomy. No doubt the Hardwick Court would uphold the ban on homosexual marriage, but it could scarcely do so on the ground that the right of privacy is limited to matters of family, marriage and procreation.

The implications of Hardwick are thus more far-reaching than "judgment by pigeonhole" would suggest.17 The Court's opinion not only placed non-family matters outside the scope of federal privacy rights but also embraced a confined definition of the family. More fundamentally, Hardwick opened the way for significant restrictions even on family-related claims, by repudiating the basic reasoning of Roe $v$ Wade. The Court in Roe had relied on historical and prudential arguments to invalidate state controls on abortion. ${ }^{18}$ In Hardwick, the Court paid lip service to such historical arguments and ignored prudential ones.

The Hardwick opinion noted that "[s]odomy was a criminal offense at common law" and that "[p]roscriptions against that con-

14 If heterosexual relations can strengthen family ties and thereby contribute to the stability of the family unit, the same may hold true for homosexual relations between strongly committed individuals. Of course, many homosexuals have no children, but that is also true of some heterosexual couples.

1s See Baker v Nelson, 291 Minn 310, 191 NW2d 185 (1971); Jones v Hallahan, 501 SW2d 588 (Ky App 1973).

${ }^{18}$ Compare Baker, 191 NW2d at 186 ("The institution of marriage as a union of man and woman, uniquely involving the procreation and rearing of children within a family, is as old as the book of Genesis.") with Hardwick, 478 US at 191-192 ("No connection between family, marriage, or procreation on the one hand and homosexual activity on the other has been demonstrated ... . Proscriptions against that conduct have ancient roots.").

${ }^{17}$ Stoddard, 54 U Chi L Rev at 653 (cited in note 1).

${ }^{18}$ Roe, 410 US at $129-52$. 
duct have ancient roots."19 The Court thereby sought to distinguish the historical analysis in Roe $v$ Wade, which had struck down broad proscriptions on abortion after noting that "abortion laws ... are of relatively recent vintage." ${ }^{.20}$ However, the common law controls on homosexual conduct encompassed considerably less than the Hardwick opinion implies. In Rex v Samuel Jacobs, ${ }^{21}$ one of the earliest reported cases on sodomy, the court specifically held that the criminal prohibition against sodomy did not apply to oral sex. The holding of the Jacobs case was widely accepted, and as a result there was "almost complete accord" among commentators that "at common law commission of the crime [against nature] required penetration per anum, and that penetration per os did not constitute the offense." ${ }^{12}$ Since the Hardwick case arose out of an incident of oral sex, ${ }^{23}$ the Court's insistence upon focusing on the Georgia statute as applied should have led to a recognition that "[p]roscriptions against that conduct" do not have the "ancient roots" claimed by Justice White. ${ }^{24}$ Indeed, it is hard to resist the conclusion that criminal sanctions against oral sex, like the sanction in Roe $v$ Wade, "are of relatively recent vintage."25

Finally, the Hardwick opinion also rejected the policy reasons articulated in Roe $v$ Wade. In Roe, the Court relied not only on historical considerations but even more emphatically on both the substantial "detriment that the [abortion law] would impose upon the pregnant woman"26 and the limited interests of the state during early stages of pregnancy. ${ }^{27}$ The Hardwick case plainly rejects this focus on detriment and utilitarian state interests, finding it sufficient that Georgia's sodomy law, as applied, rests on "majority sentiments about the morality of homosexuality ...."28

Yet the state interest in preserving majoritarian moral values, which the Court recognized in Hardwick, was also implicated in Roe $v$ Wade. The moral values expressed in the two cases-abhorrence of homosexual sodomy in one, and of abortion in the other-are not identical, but the Court has suggested no rea-

\footnotetext{
19478 US at 192.

20410 US at 129.

211 Russ \& Ry 331, 168 Eng Rep 830 (1817).

22 State v Morrison, 25 NJ Super 534, 96 A2d 723, 725 (1953).

${ }^{23}$ Atlanta Constitution, $\S \mathrm{A}$ at 7 (Sept 8, 1986).

24478 US at 192.

${ }^{25}$ Roe, 410 US at 129.

${ }^{28}$ Id at 153.

27 Id at 162-64.

${ }^{28}$ Hardwick, 478 US at 196.
} 
son why anti-sodomy values are more deserving of government expression than anti-abortion values. Moreover, Roe $v$ Wade involved important state interests in protecting potential life and maternal health, which had no counterpart in the Hardwick case. Given comparable moral values and the larger utilitarian interests present in the abortion cases, it seems implausible to suggest that Georgia put forward a stronger claim for regulation ${ }^{2 \theta}$ than Texas had advanced in Roe $v$ Wade.

Of course, it is more difficult to compare the detriment imposed on the parties in the two cases, since the activities regulated by abortion and sodomy laws are totally different. It seems clear, however, that the burden imposed by the Georgia statute, if fully enforced, will be very substantial. For a person who is exclusively homosexual rather than bisexual, compliance with Georgia law will mean a continuing abstinence from sexual intercourse. If such forced abstinence were tolerable-even in a less extreme form-for heterosexuals, there would be few occasions for abortion except in cases of rape. ${ }^{30}$ Perhaps those who doubt that the burden of complying with sodomy laws is comparable to that imposed by abortion laws should ask themselves how many individuals would elect to have abortions if the inevitable result of the abortion procedure were to make sexual intercourse impossible in the future. Not surprisingly, the Court made no suggestion in Hardwick that the burden of complying with sodomy laws is less substantial than the burden imposed by abortion laws.

It is apparent that neither history nor personal detriment, which provided the underpinnings for the decision in Roe $v$ Wade, can explain the outcome in Hardwick. Instead, the Hardwick opinion relied on institutional concerns, arguing that " $[t]$ he Court is most vulnerable and comes nearest to illegitimacy when it deals with judge-made constitutional law having little or no cognizable roots in the language or design of the Constitution." 31 Yet it was these very concerns that the Roe decision had conspicuously ig-

29 Georgia did not claim that its statute had been enacted in response to the AIDS crisis, and the Court did not rely on any health-related interest in sustaining it. But see Brief of David Robinson, Jr., Amicus Curiae (arguing that recognition of right to commit sodomy would compound the AIDS crisis).

${ }^{30}$ Sometimes abortions are available, as in cases involving adolescents, even though abstinence is not only tolerable but desirable. In the case of adolescents, however, abstinence is a temporary condition rather than a permanent one. Enforced abstinence on a permanent basis would obviously be a heavy burden for most adults. See Donald H. Regan, Rewriting Roe v Wade, 77 Mich L Rev 1569, 1594 (1979) ("having sex may be more a matter of choice than eating, but it is an act to which most of us feel a strong compulsion").

${ }^{31}$ Hardwick, 478 US at 194. 
nored. ${ }^{32}$ Given the striking conflict between the Hardwick opinion and the rationale of $R o e$, it must be asked whether the real target of the Hardwick case was homosexual sodomy, as Mr. Stoddard believes, or the right of privacy in general and the Roe decision in particular. Of course, the Hardwick Court did not overrule Roe, but it has undermined Roe in much the same way that National League of Cities $v$ Usery ${ }^{33}$ had been undermined long before it was overruled by Garcia. ${ }^{34}$ Thus, even if the specific holding of Roe remains intact, the contours of the right of privacy have been significantly altered by Hardwick.

\section{II.}

The tension between Hardwick and Roe strongly suggests that constitutional protection for privacy interests depends largely on whether five Justices can be found who are sympathetic to the claim of a particular litigant. ${ }^{35}$ It is relatively easy for members of the Court-all of whom have families of their own-to identify with the problem of an unwanted pregnancy, but not so easy for them to identify with Michael Hardwick. One can understand, therefore, why Mr. Stoddard attributes Hardwick to the Court's distaste "for the conduct under scrutiny."

However, it is not merely a hostile judicial attitude that accounts for the result in Hardwick. The very nature of substantive due process, with its reliance on nontextual constitutional imperatives, made it almost inevitable that the Court would draw artificial lines at some point-perhaps at consensual incest or sadomasochism, if not at homosexual sodomy. Earlier cases had said simply that "certain" personal rights were entitled to heightened constitutional scrutiny. ${ }^{37}$ But a rule giving heightened protection to certain undefined rights is inherently unstable in the absence of adequate standards for determining which nontextual rights are entitled to special protection and which are not. The dissent in Hardwick said that substantive due process rights are protected "because they

${ }^{32}$ See 410 US at $152-53$, tracing the judicially recognized right of privacy.

33426 US 833 (1976).

${ }^{34}$ EEOC $v$ Wyoming, 460 US 226 (1983); Garcia $v$ San Antonio Metropolitan Transit Authority, 469 US 528 (1985) (overruling National League of Cities).

${ }^{35}$ The obvious difficulty of defending this approach to constitutional adjudication may contribute to the apparent desire of some members of the Hardwick majority to restrict or abandon the privacy analysis of earlier cases.

${ }^{38} 54 \mathrm{U}$ Chi L Rev at 649 (cited in note 1).

${ }^{37}$ See, for example, Whalen $v$ Roe, 429 US 589, 599-600 (1977); Roe $v$ Wade, 410 US at 152. 
form so central a part of an individual's life," and the opinion noted that individuals may "define themselves in a significant way through their intimate sexual relationships with others. ..."38 Yet those points cannot serve to distinguish the cases in which due process claims have prevailed from those in which such claims were rejected. Many individuals "define themselves in a significant way" through their work, which may well form a "central . . . part of an individual's life"; but substantive due process claims in that area have been repeatedly rejected ${ }^{3 \theta}$ since the Court's disenchantment with them in the post-Lochner period. ${ }^{40}$ The conventional wisdom is that personal freedoms are to be treated differently from economic freedoms. But the Hardwick case surely does not inspire confidence in the suggestion that substantive due process will be more manageable when applied to personal values than when applied to economic values.

The Hardwick opinion mentioned, though the Court was careful not to endorse, two earlier efforts "to identify the nature of the rights qualifying for heightened judicial protection."41 Justice White wrote:

In Palko v. Connecticut [citations omitted] it was said that this category includes those fundamental liberties that are "implicit in the concept of ordered liberty," such that "neither liberty nor justice would exist if [they] were sacrificed." A different description of fundamental liberties appeared in Moore v. East Cleveland [citations omitted] where they are characterized as those liberties that are "deeply rooted in this Nation's history and tradition." 42

But the Palko test was designed only to determine which of the rights specifically enumerated in the first eight amendments would be applied against the states, ${ }^{43}$ not for the much more ambitious task of identifying specially protected interests that have no roots in the constitutional text. And despite the limited role intended for the Palko test, it nevertheless proved inadequate and was eventually abandoned. ${ }^{44}$

The Moore standard, unlike the one in Palko, did not com-

38 478 US at 204-05 (Blackmun dissenting).

39 See Ferguson v Skrupa, 372 US 726, 729-30 (1963).

to Lochner v New York, 198 US 45 (1905).

4478 US at 191.

42 Id at 191-92.

43 Palko v Connecticut, 302 US 319, 326 n 4 (1937).

4 See Duncan v Louisiana, 391 US 145, 149 n 14 (1968). 
mand a majority of the Court even when it was proposed. ${ }^{46}$ More importantly, the Moore standard cannot explain the privacy decisions that have already been rendered, ${ }^{46}$ much less resolve the difficult issues of euthanasia, ${ }^{47}$ drug usage, ${ }^{48}$ and surrogate parenting $^{49}$ that are on the horizon. Finally, as noted above, the reliance in Roe $v$ Wade on history and personal detriment has already been effectively repudiated in the Hardwick case. ${ }^{50}$ Thus the task of devising standards for determining which unenumerated freedoms are entitled to heightened protection remains intractable. It is a problem that has plagued the Court throughout the history of substantive due process, and there is no reason to believe that this problem, which continues to resist solution after many years of judicial effort, will be overcome in the foreseeable future.

Given the inherent instability of privacy analysis, even a temporary majority of the Supreme Court can bring about major changes in doctrine by granting certiorari in a large number of cases while their views command the power of five votes. Furthermore, the composition of the Court is certain to change in the near future, and it is likely that some of the strongest supporters of the right of privacy will be among the first to leave the bench. Under these circumstances, something more than the occasional fastidiousness of the Senate Judiciary Committee will be needed to forestall what Mr. Stoddard calls "lawmaking by personal predilection." 11

If I am correct that the Hardwick case is fundamentally at odds with the rationale of Roe $v$ Wade, we should begin to recog-

${ }^{45}$ See Moore v East Cleveland, 431 US 494 (1977) (Justices Powell, Brennan, Marshall, and Blackmun forming plurality).

46 Access to legal abortions can scarcely be said to be "deeply rooted in this Nation's history and tradition." Moore, 431 US at 503. It is possible, of course, to read traditions at such a high level of generality as to embrace some "right to be let alone." However, a reading of this sort is likely to draw into its orbit other activities that cannot plausibly be claimed to fall within the range of constitutionally protected rights. See, for example, Commonwealth $v$ Stowell, 389 Mass 171, 449 NE2d 357 (1983) (upholding adultery laws). Certainly the Court has identified no deeply rooted tradition that shelters abortion but not homosexual relations.

${ }^{47}$ See Matter of Conroy, 98 NJ 321, 486 A2d 1209 (1985).

t8 See United States $v$ Rutherford, 442 US 544 (1979) (rejecting a demand for Laetrile by terminally ill cancer patients); Superintendent of Belchertown $v$ Saikewicz, 373 Mass 728, 370 NE2d 417, 426 (1977) (recognizing the right of a leukemia patient to refuse chemotherapy).

19 See Matter of Baby $M, 109$ NJ 396, 537 A2d 1227 (1988).

${ }^{\text {so }}$ See text at notes 18-30.

${ }^{51}$ Stoddard, 54 U Chi L Rev at 656 (cited in note 1). 
nize the need for an alternative to conventional privacy analysis. ${ }^{52}$ Advocates in the Supreme Court have too often used privacy case law as a convenient substitute for careful consideration of the constitutional text. Roe $v$ Wade provides an instructive example. Analysis of the right to terminate a pregnancy should have focused, not on the vagaries of the Due Process Clause, but on the text of the Thirteenth Amendment and its explicit ban on involuntary servitude. The Thirteenth Amendment, which has been called "a charter of universal civil freedom for all persons," was intended "to make labor free ... by prohibiting that control by which . . . personal service ... [is] coerced for another's benefit."133 This national policy against involuntary servitude prohibits the enforcement of contracts for personal services even when entered into voluntarily and even when payment for the services has already been fraudulently obtained. ${ }^{54}$

Whether a ban on abortion would result in involuntary servitude within the meaning of the Thirteenth Amendment is a complex question. One writer has noted that pregnancy does not involve the kind of labor contemplated in the Court's Thirteenth Amendment opinions. ${ }^{55}$ But even if pregnancy itself does not involve labor, the delivery surely will. ${ }^{56}$ Moreover the issue is not simply whether the framers anticipated the application of the Thirteenth Amendment to unwanted pregnancies; almost certainly they did not, just as they perhaps did not expect the Equal Protection Clause to require the invalidation of school segregation laws.

s2 In an insightful essay, Professor Sunstein notes that the Equal Protection Clause is sometimes a useful alternative to the Due Process Clause. Cass R. Sunstein, Sexual Orientation and the Constitution: A Note on the Relationship Between Due Process and Equal Protection, 55 U Chi L Rev 1161 (1988). He observes, for example, that the Equal Protection Clause might be violated by "discrimination against a class of gays and lesbians, even if ... all of them engage in activity that may be regulated consistently with the Due Process Clause." Id at 1162 n 9. Professor Sunstein does not claim that any fundamental right would be found in cases of discrimination based on homosexual activity after Hardwick. See San Antonio Independent School District v Rodriguez, 411 US 1, 33-34 (1973) (limiting the fundamental rights branch of equal protection to matters "explicitly or implicitly guaranteed by the Constitution"). But quite a different question is raised by the suspect classification branch of equal protection. As Professor Sunstein suggests, it seems clear that actions that are unprotected by the Due Process Clause may be subject to strict scrutiny when regulation is based on a suspect classification. See McLaughlin v Florida, 379 US 184 (1964) (ban on cohabitation of interracial unmarried couples violates the Equal Protection Clause).

${ }^{33}$ Bailey v Alabama, 219 US 219, 241 (1911).

st Pollock v Williams, 322 US 4, 24 (1944).

${ }^{s s}$ Regan, 77 Mich L Rev at 1619 (cited in note 30 ) ("Nor does [unwilling pregnancy] involve labor of the sort [Justice] Hughes was referring to.").

${ }^{36}$ The widespread practice of paying compensation to surrogate mothers suggests an acceptance of the view that personal service and labor are involved. 
The question is whether the values that the framers sought to protect in the Thirteenth Amendment are in fact implicated in cases of unwanted pregnancy, regardless of what was subjectively anticipated. We should not simply assume that an obstetrician can invoke the protection of the Thirteenth Amendment upon refusing to deliver a baby, but that a pregnant woman has no protection whatever under the Amendment. It is at least arguable that a ban on abortion results in "personal service . . . coerced for another's benefit . . . ."\$57

A recent Supreme Court decision, however, could narrow the range of personal services covered by the Thirteenth Amendment. In United States $v$ Kozminski ${ }^{38}$ the Court ruled last Term that "involuntary servitude" means a condition of servitude in which a person is compelled to work through the use or threat of physical or legal coercion. ${ }^{58}$ In a concurring opinion, Justice Brennan noted that the law "prohibits 'involuntary servitude' rather than 'involuntary service," "and he offered an exceedingly narrow definition of the former: " 'servitude' generally denotes a relation of complete domination and lack of personal liberty resembling the conditions in which slaves were held prior to the Civil War." Court said that Justice Brennan's "formulation would be useful"'1 if limited to cases involving the use or threat of physical or legal coercion.

Clearly, an endorsement of this definition of "servitude," if applied to the Constitution rather than only to corresponding statutory language, would portend a narrow construction of the Thirteenth Amendment, and would preclude its application to antiabortion laws. Nevertheless the holding in Kozminski was directed solely to the meaning of the term "involuntary," and did not extend to any redefinition of "servitude." 62 A decision to limit the

B7 Bailey, 219 US at 241; Regan, 77 Mich L Rev at 1619 (cited in note 30).

58 108 S Ct 2751 (1988).

s9 $108 \mathrm{~S} \mathrm{Ct}$ at 2760 . Although the issue before the Court called for statutory interpretation, one of the statutes in question incorporated the Thirteenth Amendment by reference. Accordingly, the Kozminski case provides an authoritative view of the scope of the Thirteenth Amendment, as reflected in prior decisions. Because Kozminski involved a criminal prosecution, which requires "a definite standard of guilt," the Court did not address the potentially broader scope of the Thirteenth Amendment that might surface in future decisions. Id at 2759-61.

${ }^{\circ 0}$ Id at 2769 (Brennan concurring). Justice Brennan addressed only a statutory question having no constitutional implications, since he found it unnecessary to interpret the statutory provision that incorporates the Thirteenth Amendment. Id at 2765-66 n 1, $2769 \mathrm{n}$ 8 (Brennan concurring).

${ }^{61}$ Id at 2764 (dictum).

${ }^{62}$ Id at 2765. 
Thirteenth Amendment to cases of physical and legal coercion has no implications for anti-abortion laws since those laws plainly involve legal coercion. ${ }^{63}$ But it is apparent that quite an elaborate argument will be needed to explicate the relationship between abortion and the Thirteenth Amendment. It is that relationship rather than the substantive due process formula that should have been the first subject of inquiry in Roe $v$ Wade.

Of course, whatever may be said of abortion, there are other substantive matters that cannot be brought within the specific provisions of the Constitution. But the Hardwick case shows that the right of privacy is itself an unreliable safeguard for nontextual rights. It is this unreliability that one might have expected Mr. Stoddard to protest, while registering his objections to the Hardwick decision. Instead, he called Hardwick a case of "lawmaking by personal predilection" 64 and apparently failed to notice that this characterization could as readily be applied to privacy decisions that he would support.

es Obviously, the Thirteenth Amendment, as interpreted in Kozminski, would not apply to psychological pressures brought to bear on a pregnant woman by members of her family or by others.

o4 Stoddard, 54 U Chi L Rev at 656 (cited in note 1). 
